日悘外医会誌 $53(1), 93-97,1992$

症 例

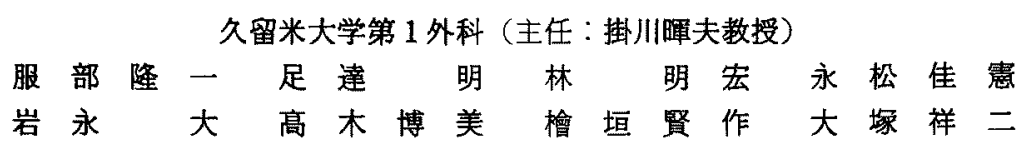

消化管のガス像を伴わない横隔膜へルンフ 2 症例をMRIにて術前に診断し得たので 報告する。1 例は Bochdalek 孔へルニアであり，むう1例は Morgagni 孔へルニアで あった，両症例とす腫瘤陰影は単純 X 線撮影では均一な陰影を示し，診断が困難であっ たか，MRIにて横隔膜下組織との連続性を証明できた。脱出贜器は後腹膜脂肪および大 網であった。この上5に術前に確定診断を得ることは治療方針の决定や，手術フブロー 千の適切な選択にる重要である.MRI は血管造影や気腹などに比較して侵站が少ない点 る有利である. 本疾患が疑われた場合は，CT ととすにぜひ行ってみるべき検査と考克ら れる.

臬引用語：横隔膜へル $=7, M R I$

\section{糧 雷}

横隔膜へルニアは, その発生部位により食道裂孔一 ルニフ, Bochdalek 孔へルニフ, Morgagni 孔へル ア等に分類され，その原因に上り先天性扰よび後天性 （外第性へルニフを含を）に分類される。またへルニア 門, ヘルニア变, ヘルニア内容の三者を有するものを 真性一ルニア，単なる組織脱出を仮性へルニアとする 分類もある、本症の診断は食道裂孔ールニアが上部消 化管造影により比較的容易になされるのに対し，その 他のるのでは診断に苦虑する場合がある，脱出臓器が 腹腔内の管腔㺂器であれば胸部 X線像で胸腔内に消 化管のガス像を諮めることにより診断が下されやすい

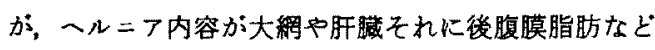
のガスを有しない充実性の茷器や組織の場合は肺腫 晹，䊮隔腫湯，横隔膜腫瘍，膿胸，結核等の他の疾患 と椌診されることもあり注意を要する，今回われわれ は, 診断にMRIが有用であった横隔膜へルニアの 2 症例を経験したので若干の考察を加えて報告する。

\section{症例}

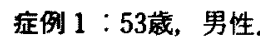

主訴：全身僚急感.

家族歴: 父親一胃癌。

既往歴：特記すべきのなし。

1991年 4 月 16 日受付 1991 年10月14日採用
現病歴：昭和63年 8 月全身隐急を自覚し近医受診寸 るも特に異常ないといわれる，その後も症状持続する ため，平成元年 3 月当院内科を受猃する．その際，胸 写にて左横隔膜上の異常陰影を指摘され，精查目的で 入院となる. 断尿, CT, 血管造影(大動脈, 左腎動脈, 左横隔膜動脈，腹腔動脈）施行する確定診断がつか ず, CT 值から脂肪よりなる腫瘤と考えられ, 脂肪瘇の 診断にて外来経過観察となった，外来にて経過観察中 にMRI を施行したところ横隔膜下左腎上部の後腹膜 脂肪との連続性が諗められ, Bochdalek 孔へルニアと 診断され，手術目的にて平成元年11月当科入院となる.

入院時現症：身長 $161 \mathrm{~cm}$, 体重 $50 \mathrm{~kg}$ ，体格中で栄盖 状態良好. 脈不整なく呼吸も平静で䝷血，黄疾等も認 められなかった．聴打診上，胸腹部ともに異常所見は みられなかった。

臨床検査成綨：血液および血清学的娭查では特に異 常なし、呼吸循環器系も異常を認めなかった，胸部 X 線側面像（図 1 ）で左横隔膜に接するように辺縁明膫 な腫瘤影を認め，立ち上がりは鉠で約 $5 \mathrm{~cm}$ の大きざ あり，大きさは，発見時より変化していない，CT 検查 (図 2)ではそのCT 值より脂肪組織より成っていると 推定されるるのの，横隔膜下との交通は確認出来な かった，MRI 検査の冠状断像所見（図 3）にて横隔膜 を貫いて左堅上部の後腹膜脂肪と重続性を認め，横隔 膜ヘルニア (Bochdalek 孔へルニア) の猃断のもとに 


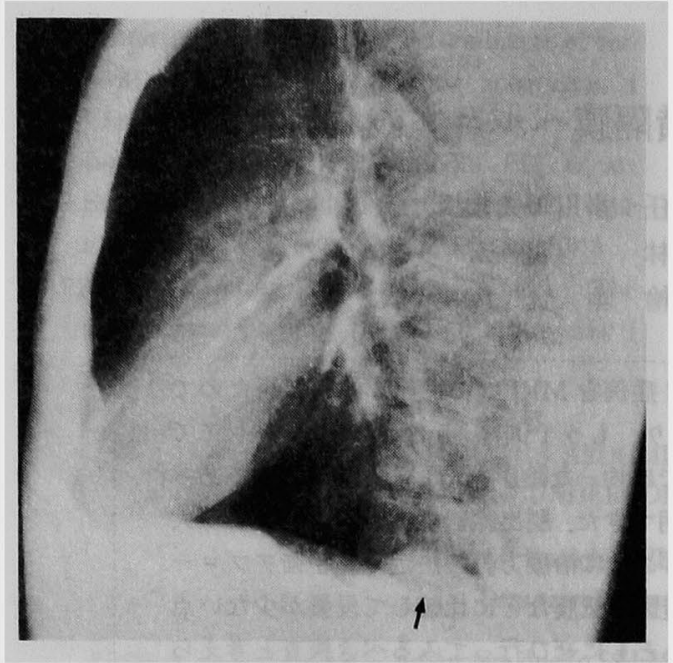

図 1 胸部 X 線側面像：左横隔膜上背側に, 立ち上が り鈍で辺縁明瞭な腫㿇影を認める $(\rightarrow)$. 大きさは5 $\mathrm{cm}$ で均一な陰影である。

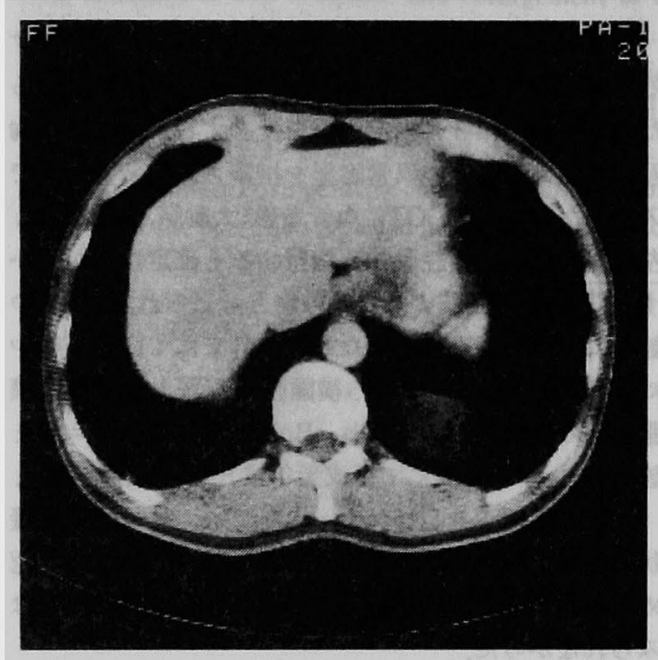

図2 CT 像：CTにても内部は無構造である. CT 值 は脂肪等に一致する。

手術を行った。

手術所見：アプローチは前方腋䆟切開の第 6 胁間開 胸とした。横隔膜の後側方に, 半球状 $5 \times 4 \mathrm{~cm}$ の董瘤を 認め，黄色軟であり表面は胸膜に被われていた，胸膜 を切開すると，内容は脂肪よりなっていた。 その脂肪 織を横隔膜より剝離すると背側にて横隔膜に欠損部 $(2 \times 3 \mathrm{~cm})$ が認められ，その孔より指診にて左腎を触知



図 3 MRI 冠状断像：瘇瘤は横隔膜上にあり,一部で 横隔膜を英いて $(\rightarrow)$ 左堅上極の脂肪と連続性が認 められる。

した，腫瘤はその孔を介し後腹膜の脂肪織と連続性が 認められた，脱出した部分の脂肪織を切除した後，一 ルニフ門を繾合閉鎖し，手術終了した。

術後経過：経過良好にて, 術後11日目に退院となる。 症例 $2: 76$ 歳, 女性。

主訴：咳。

家族歴：特記すぺきことなし。

既往歴：メニエル症候群，僈珄関節リウマチ。

現病歴：上記疾患を近医にて治療中であったか，感 冒様症状のため平成 2 年 3 月に胸写を撮ったところ右 下肺野に腫瘤状の異常陰影が認められた。 その後内服 治療にて呼吸器症状は消失した。 5 月に胸部 CT 施行 し, 綎隔 lipoma の診断をらける. その後, 外来にて経 過観察中，9月および12月の胸写にて軽度の増大㑯向 が認められた為, 精査目的にて当院紹介入院となる.

入院時現症：身長 $140 \mathrm{~cm}$, 体重 $42 \mathrm{~kg}$, 体格小, 栄養 状態良好で肥満あり. 体温, 脈拍正常で呼吸状態す平 静. 貟血, 黄庭等認めず, 表在リンパ節も属大なし. 聴打診上，胸部に異常を認めず，腹部も平坦で，正痛 なく，腫瘤む触知しなかった。

郜床検查成繥：血液, 血清学的検査では特に異常認 めず，ECG も異常を認めなかった。呼吸機能検查にて VC $1.95 l$, \% VC 94.66\%, 1 秒量1.59l, 1 秒率 $84.13 \%$ 之異常なし，血液ガスも正常範囲であった。胸部 X 線 後前像では右下肺野心横隔膜角部に鵎卵大の内部均一 




図 4 胸部 X 楾後前像：右心横隔膜角部に内部均一 な腫慮影を認め，辺縁は明瞭である．ガス像は認め られない.



图 5 胸部 X 線側面像：尰瘤は胸骨と横隔膜に接す るよらに存在する。

な腫瘤影を認める(図 4 )。側面像でも胸骨，横隔膜に 接する腫瘤が認められた（図 5). 胸部 CT (図6)に ては，前縦隔に心䐵に接して内部が均一な腫瘤がみら れ，そのCT 值は脂肪組穖と一致する値であった。 MRI 冠状断像での所見（図 7) をみると fat の intensity に一致する腫瘤が一部横隔膜下と交通が認められ た. 以上の結果より, 横隔膜へルニア(Morgagni 孔へ

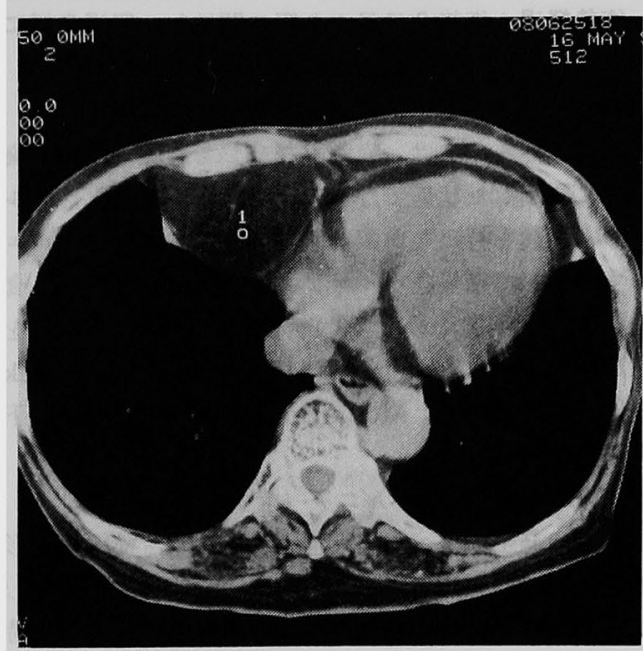

図6 CT：隀瘤内部に特別な構造は無くそのCT 値 は脂肪に一致する。

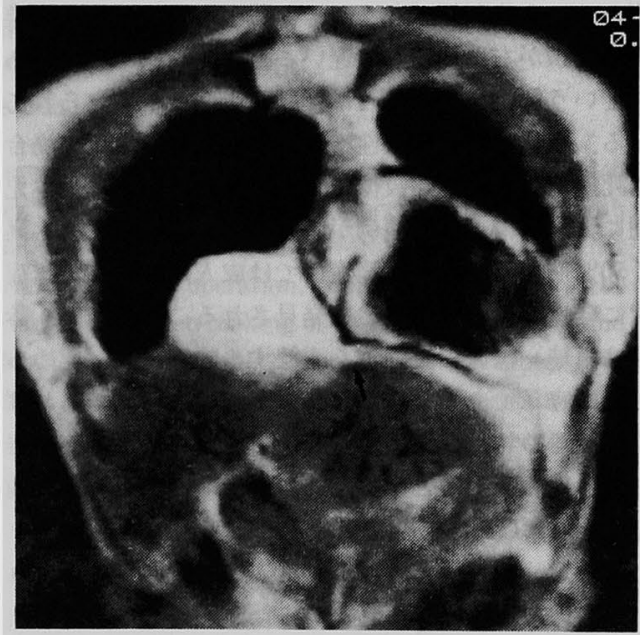

図 7 MRI 冠状断像：脂肪の intensityに一致する 腫瘤が一部横隔莫下と連続しているのが認められる $(\rightarrow)$.

ルニア）の診断にて手術を行った.

手術所見：全麻下に約 $10 \mathrm{~cm}$ の上腹部正中切開にて 開腹すると, 右胸肋三角部にへルニアを認め, 大網が 脱出していた. ヘルニア䗸と大網との痹着はみられず, 容易に腹腔内に還納された。へルニア襄を腹腔内に反 転させ結禁切除し，へルニフ門を縫縮し手術を終了し た。 
術後経過：術後 2 日目より経口開始し，経過良好に て、郝後10日目退院となる。

\section{考 察}

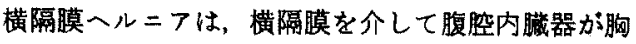
空内に脱出した状態で，へルニて整を有する真性へル ニフす, 持なない䑏器脱出と呼ぶべき仮性へルニ フも一括して横隔膜へルニフと呼ばれる，この内，食 道裂孔一ルニアが最む多く非外侮性ヘルニフの3/4を 占めるとされている1). 残りの大部分を Bochdalek 孔へル =アが占め, Morgagni 孔へルニアは $3 \%$ 以下 とする報告が多い(5)。

\section{Bochdalek 孔へルニア（症例 1$)$}

本症の発生はすべて先天性と考えられ，横隔膜が形 成される過程中に胸腹膜㩐 (pleuroperitoneal canal) から腹腔内臓器が胸腔内人脱出すると一ルニア变を持 たない仮性へルニフとなり，横隔膜の融合形成後の笳 形成が不十分な時期に脱出がおこるとへルニて壁を有 ナる真性へルニアになるといかれている，発生側は右 側の 4〜8倍左側に多く，その理由としては左胸腹膜 漸の閉鎖が右に比較して遅いことや，右には肝䐬があ るといら解剖学的なことが影暗していると考えられて いる. 全体の $90 \%$ を仮性へルニアが占め, 重症の場合 は死库例す多い，呼吸循環障害が激しいために新生児 期に緊急手術となる症例が多く314，よって死亡率も高 く50\%前後とされる，軽症例では成人になるまで無症 状に経過し，胸写で偶然に発見されることも多い，診 断は単純レ線像で腹腔より連続する腸管がスが認めら れれば容易である，消化管造影が可能な情況であれば


の場合は診断困難となる。この症例も内部が均一な睡 瘤であり，CTにて脂肪組㖪より成るるのと想像され たが確定診断を得られなかった，血管造影も施行され たが有力な情報は得られなかった，最終的に誩断の决 め手になったのは, MRIによる後腹膜脂肪との連䋨性 の証明であった．CTにてい連続性を証明出来る場合 があるとの報告すあり"，本定を念頭におき CT 像の 読影を十分に行い、一ルニアが疑われた場合はMRI を施行してみるべきであると考えられる。気腹む有力 な診断法とされていたか，画像診断の発達した今日， 第 1 選択とすへき娭査ではないと思われる，治療に関 しては，新生児重症例户成人無症状例でる消化管等の 嵌頓の危険性があるむのの手術適応は異論の無いとこ ろであろう。しかし今回の症例の上うに成人無症状例 に対しての手術適応は意見が別れる。今回は最終彭断
を得たいといら本人の強い希望があり，嵌頓の危険性 る考虑し手術施行した。フプローチは腹腔内の操作が 不必要と考え，開胸にて行った。この視野にて瘜着刹 離す容易でールニフ門の閉鎖す十分に可能であった。

\section{Morgagni 孔ヘルニア（症例 2)}

本ヘルニアは，横隔膜ヘルニアのなかです食道裂孔 ヘルニアや Bochdalek 孔へルニアに比較して稀な族 患とされている。報告者により嚬度は異なるが 2 一 $3 \%$ 程度之される5). 僙隔膜の胸骨付着部之助骨付 着部の間にある胸肋三角と西ばれる抵抗の弱い部分に 生ずるールニアで，胸骨後へルニフ (retrosternal hernia)とも乎ばれる. 右を Morgagni，左を Larey 孔へ ルニフと区別して呼ぶことすある，好発年龄は乳幼児 と高龄者であり，乳幼児のすのは胸肋三角部の筋肉発 育不全に起因する先天性因子が大きく，高路者のすの は肥满や肺気䜿なとにより胸郭の抁張がおこり胸肋三 角部の抵抗減弱をきたす後天性の因子が関与している と考えられている。また心缄の位固により右が数倍多 いまた，女性が男性の3 倍程多いと報告されてい る(5). 本へル=フの多〈は真性へルニアで, ヘルニフ 内容は横行結腸, 大㮶, 肝, 小腸および胃の順に多い. 症状はへルニアの内容と脱出量にすよるが Bochdalek 孔へルニフに比へると軽症例が多く，特に高龄 者の場合愁訴が少なく，本症例のように偶然の胸部上 線像にて発見されることも多い7.診断は, 胸部 X 線像 にて心横隔膜隅に境界明瞭な腫瘤影が存在し側面像に て前縦隔である場合は本症の存在を念頭に扰くことが 大切である，さらに消化管内のガス像が認められた場 合は容易に診断がつけられる。そのような所見が無い 均一な隀溜影の場合は，腹腔内との連続性の証明が最 終的に必要になる，その目的のために気腹や血管造影 も考えられるが，侵留度からしてCTゃMRIのはう がよりすくれていると思われる。今回の症例むMRI にて連続性が証明されたため血管造影等は施行してい ない，治療に関しては無症状の場合でも嵌頓の危険を 考魔して，手術すべきであるとの意見が多い，手術の フプローチは症例により異なると思われるが，本症例 では開腹にて行った。理由として脱出䁍器の状態, 特 に還納後の情報が得られると考えたからであった。 ルニフ链の切除およびヘルニフ門の閉鎖補強も腹腔内 からの操作で十分であった。

\section{結 語}

以上， 2 例の横䧣膜へルニフ症例を紹介したが，そ の診断にあたり大切なことはまず本症を疑らことであ 
る.として最終的には腹腔内との連続珄を証明するこ とであるが，その手段として MRIは非常に有用で あった。術前に確定診断を得ることは治廖方針の決定 や手術のアプローチ決定に成して重要である。前大 塥などが脱出䑏器である場合の術前猃断率は非常に低 かっだが，画像診断の発達により今後高くなってい くと期待される.

$$
\text { 文献 }
$$

1) 富田友幸, 高㰌唯郎：横隔膜ヘルニ7, 滗島 任,

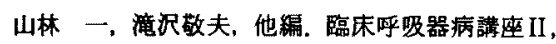
金原出版，東京，1978，p420-423

2）福原德光，松宫亘夫：横隔獏疾患，北本 治編. 乎吸器病学. 医学書浣, 東京, $1970, \mathrm{p} 842-852$

3）中原数也, 岡田 正, 島崎靖久他：ボクダレックー ルニフK拈ける呼吸循環不全, 日胸外会誌 28 :

$$
1413-1420,1980
$$

4）小野誠治，杜若陽喛，星 博昭他：Morgagni 孔一 ルニフと Bochdalek 孔ヘルニフの合併症, 臨放線 $30: 509-512,1985$

5) 丸野 要, 加藤博司, 二村 明他: Morgagni 孔人 ルニフの2治段例, 外科猃寮 $22: 349-353,1980$

6）飯挥 亮，横沢忠夫，山崎芳彦他：Morgagni 孔一 $ル=>の 4$ 治験例, 外科 $40: 557-561,1978$

7) 池田道昭, 山根喜男, 萩原 界他: 横隔膜モルガ ニー孔一ルニフの1治験例, 外科診療 $623-626$, 1982

8) 村山祐一郎, 神吉 豊, 中村昭光他：Morgagni 孔 ヘル $=7 の 1$ 治験例と本邦報告例の検討, 胸部外 科 $35: 751-758,1982$

\title{
TWO CASES OF DIAPHRAGMATIC HERNIA PREOPERATIVELY DIAGNOSED BY MRI
}

\author{
Ryuichi HATTORI, Akira ADACHI, Akihiro HAYASHI, Yoshinori NAGAMATSU, Dai IWANAGA, \\ Hiromi TAKAGI, Kensaku HIGAKI and Shoji OHTSUKA \\ First Department of Surgery, Kurume Medical School
}

\begin{abstract}
We recently experienced two cases of diaphragmatic hernia accompanied by no gastrointestinal gas, which could be preoperatively diagnosed by MRI. One was Bochdalek hernia, and the other was Morgagni hernia. In both cases, it was difficult to diagnose, because of homogenous shadows on chest X-ray films. MR imaging showed that each mass was continuous with the subphrenic tissue. As a result of operation, prolapse organs were the retroperitoneal fat tissue and greater omentum. It is important for decision-making of therapeutic methods and proper approach for operation to establish the definitive diagnosis preoperatively. MRI has an advantage over angiography and pneumoperitoneum in having lesser invasion, and its combined use with $\mathrm{CT}$ is recommended when this disease is suspected.
\end{abstract}

